\title{
The influence of microorganisms of the Arctic paleoecosystems on the morphometric parameters and the cytogenetic apparatus of Allium cepa
}

\author{
Aleksandr A. Kastornov*, Andrey M. Subbotin, and Sergei A. Petrov \\ Tyumen Scientific Center SB RAS, 625026, 84, Malygina str., Tyumen, Russian Federation
}

\begin{abstract}
The experiment studies the influence of microorganisms of the genus Bacillus from dispersed soils, which passed into a frozen state during the Holocene period, on the morphometric parameters and differentiation of Allium cepa cells. During the experiment, it was found that bacteria of the genus Bacillus can change morphometric parameters (there is a delay in the growth of roots and shoots, their length and number decrease). The influence of the studied strains from frozen rocks is manifested at the cellular level, changing the mitosis of the cells of the meristematic root tissue of Allium cepa. It is expressed both in the mitosisstimulating effect and in the limitation of the proliferative capacity of Allium cepa cells. Thus, the behaviour of microorganisms in the Arctic paleoecosystems in the environment, their use in the economy, agriculture, and medicine are promising and topical issues. In addition, the question of the influence of relict microbiota on modern biological objects and, first of all, on their cellular apparatus remains understudied. The study of permafrost microorganisms makes it possible to better understand the evolution of adaptive characteristics of modern biological objects to the cold and subsequently move on to the development of technologies pointed at using the adaptive potential of microorganisms.
\end{abstract}

\section{Introduction}

The current state of the cryosphere characterizes by the presence of atmospheric, hydrospheric, ground and underground ice and microbiota in dispersed soils that have passed into a frozen state $[1,2]$. The dispersed watered permafrost rocks are widespread in the northern hemisphere, and their age reaches hundreds of thousands and millions of years [3]. They contain viable microorganisms, which have a close year of age to the age of frozen soils [4]. Currently, due to global climate change, including its warming, happens the degradation of permafrost rocks and the release of relict microbiota. At the same time, there is not enough data on their impact on modern living systems. It is estimated that since the beginning of the industrial era, the average air temperature on our planet has increased

\footnotetext{
*Corresponding author: AlexKastornov@yandex.ru
} 
by more than 1 degree. And the process of global warming in the Arctic is happening many times faster.

The Bacillus sp. from permafrost rocks were preliminary tested on Drosophila melanogaster and laboratory mice. It has shown its immunostimulating effect, increased lifespan and improvement of their physical condition [5]. At the same time, bacteria of the strain Serratia fonticola from permafrost rocks led to the destabilization of the karyotype, and they activated the somatic mutagenesis of the meristematic root tissue of Allium cepa L. Also, the bacteria cause such abnormalities of the cell nuclear apparatus as fragments, bridges, lagging and runaway of chromosomes [6]. Consequently, the study of microorganisms of the Arctic paleoecosystems, their behavior in the external environment and the possibility of their use in the economy is a promising and relevant area of research.

The aim of the research is to assess the influence of microorganisms of the genus Bacillus from the Arctic paleoecosystems on the morphometric parameters and cytogenetic apparatus of Allium cepa.

\section{Methods}

The Allium test based on the Allium cepa plant was used to estimate the mutagenic, mitosis-modifying and toxic effects of microorganisms of the genus Bacillus from dispersed soils that passed into a frozen state during the Holocene period. In this case, the morphometric parameters and phases of cell division of Allium cepa were recorded.

The object of the study was the feathers and roots of Allium cepa onion seedlings of the Stuttgarten Riesen variety. The average weight of the bulbs was $6 \mathrm{~g}$, the diameter was 1.75 $\mathrm{cm}$. Microorganisms from the permafrost rocks were taken from the sediments of the Upper and Middle Pleistocene of the IV marine terrace (mIII1, mII2 -4), which locates in the area of Tarko-Sale town (north of Western Siberia). We used bacteria of the genus Bacillus (strains 2-06-TS1, 875 TS, 948P-1 TS, 1257 TS and 312 TS), registered in the Russian National Collection of Industrial Microorganisms (registration No. B-12402, B-12242, B12245 , B-12243 and B-12244, respectively). Cultivation of bacteria was carried out on slant nutrient agar (FPH - agar, Obolensk. TU 9398-020-780956-2006) in a thermostat at $\mathrm{t}=26^{\circ}$ $\mathrm{C}$ for 48 hours. Then the microorganisms were washed with $5 \mathrm{ml}$ of distilled water. The concentration of microorganisms was measured by the Koch method (the serial dilution method) [7]. In the experiment, we used a concentration of $1 \times 10^{9}$ microbial cells in $1 \mathrm{ml}$ of distilled water.

The sample in each experimental group consisted of 3 bulbs. Onions were grown at room temperature in appropriate aqueous suspensions of bacterial cells for 7 days. The roots of seedlings grown on distilled water served as control No. 1. The roots of seedlings grown on the FPH nutrient medium served as control No. 2. The generally recognized Allium test was used for cytogenetic studies according to the standard method $[8,9]$. The prepared preparations were analyzed under a Zeiss Primo Star microscope using PlanAchromat 40x / $0.65 \mathrm{pp}: 0.48 \mathrm{~mm}$ objectives.

While studying morphometric parameters, there measured the length and number of roots and feathers of each bulb. At all stages of the life cycle, from 6468 to 8725 cells were analyzed. In the course of cytological analysis, the mitotic index was calculated using the formula:

$$
\mathrm{MI}=(\mathrm{P}+\mathrm{M}+\mathrm{A}+\mathrm{T}) / \mathrm{N} * 100 \%,
$$

where $(\mathrm{P}+\mathrm{M}+\mathrm{A}+\mathrm{T})$ is the sum of cells at the stage of pro-, meta-, ana-, and telophase, and $\mathrm{N}$ is the total number of analyzed cells. 
The investigated qualitative and quantitative characteristics were statistically processed using the integrated software package "SPSS Statistics 21 for Windows". Characteristic distributions, assessment of distribution characteristics and intergroup differences (mean, standard deviation, Mann-Whitney U-test, Pearson $\chi^{2}$ test) were calculated. Differences were considered significant at $\mathrm{p}<0.05$.

\section{Results}

Analysis of the growth and development of onions, when treated with strains of microorganisms from frozen rocks, showed that strains of microorganisms delay the development of the root system of onions in contrast to neutral control 1 (table 1).

Table 1. The influence of microorganisms on the development of the root system, vegetative part and the characteristics of cell division of Allium cepa.

\begin{tabular}{|c|c|c|c|c|c|c|c|}
\hline & Control 1 & Control 2 & 875 TS & $\begin{array}{l}\text { 2-06- } \\
\text { TS1 }\end{array}$ & $\begin{array}{c}948 \mathrm{P}- \\
1 \mathrm{TS}\end{array}$ & $312 \mathrm{TS}$ & $\begin{array}{c}1257 \\
\text { TS }\end{array}$ \\
\hline \multicolumn{8}{|c|}{ Root system of Allium cepa, cm } \\
\hline $\mathrm{N}$ & 93 & 59 & 74 & 81 & 45 & 75 & 63 \\
\hline $\begin{array}{c}\text { Mean } \pm \\
\text { Standard } \\
\text { error of the } \\
\text { mean }\end{array}$ & $4.87 \pm 0.19$ & $0.40 \pm 0.03 * * *$ & $\begin{array}{l}1.34 \pm 0.14 \\
* * * / \# \# \#\end{array}$ & $\begin{array}{c}1.66 \pm \\
0.09 \\
* * * / \# \# \#\end{array}$ & $\begin{array}{l}0.35 \pm \\
0.03 \\
* * *\end{array}$ & $\begin{array}{c}3.36 \pm \\
0.1 \\
* * *\end{array}$ & $\begin{array}{l}2.51 \pm \\
0.16 \\
* * *\end{array}$ \\
\hline \multicolumn{8}{|c|}{ Vegetative part of Allium cepa, $\mathrm{cm}$} \\
\hline $\mathrm{N}$ & 10 & 5 & 10 & 9 & 7 & 7 & 7 \\
\hline $\begin{array}{c}\text { Mean } \pm \\
\text { Standard } \\
\text { error of the } \\
\text { mean }\end{array}$ & $8.43 \pm 1.76$ & $\begin{array}{l}1.28+ \\
0.66^{* *}\end{array}$ & $\begin{array}{c}3.62 \pm 0.87 \\
* / \#\end{array}$ & 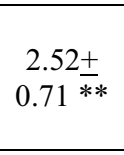 & $\begin{array}{c}1.57 \pm \\
0.62 \\
* *\end{array}$ & $\begin{array}{l}0.83 \pm \\
0.22 \\
* * *\end{array}$ & $\begin{array}{c}3.16+ \\
1.02 \\
*\end{array}$ \\
\hline \multicolumn{8}{|c|}{ Characteristics of cell division of Allium cepa } \\
\hline $\begin{array}{l}\text { Total number } \\
\text { of cells, items }\end{array}$ & 6841 & 7642 & 8602 & 6690 & 6468 & 8725 & 7529 \\
\hline Prophase, \% & $2.97 \pm 0.41$ & $\underset{* * *}{1.25 \pm 0.11}$ & $\begin{array}{c}2.0 \pm 0.16 \\
* / \# \#\end{array}$ & $\begin{array}{c}2.03 \pm \\
0.13 \\
* / \# \# \#\end{array}$ & $\begin{array}{c}0.98 \pm \\
0.08 \\
* * *\end{array}$ & $\begin{array}{c}2.79 \pm \\
0.15 \\
\# \# \#\end{array}$ & $\begin{array}{c}2.49 \pm \\
0.43 \\
\#\end{array}$ \\
\hline Metaphase, $\%$ & $2.28 \pm 0.47$ & $1.03 \pm 0.09$ & $1.24 \pm 0.11$ & $\begin{array}{c}1.85 \pm \\
0.15 \\
\# \# \#\end{array}$ & $\begin{array}{c}0.84 \pm \\
0.08 \\
* *\end{array}$ & $\begin{array}{c}1.88 \pm \\
0.15 \\
\# \# \#\end{array}$ & $\begin{array}{c}2.12 \pm \\
0.51 \\
\#\end{array}$ \\
\hline Anaphase, $\%$ & $1.87 \pm 0.39$ & $1.06 \pm 0.13$ & $1.25 \pm 0.1$ & $\begin{array}{c}2.01 \pm \\
0.17 \\
\# \# \# \\
\end{array}$ & $\begin{array}{c}0.86 \pm \\
0.06 \\
*\end{array}$ & $\begin{array}{c}1.8 \pm \\
0.13 \\
\# \# \\
\end{array}$ & $\begin{array}{c}1.91 \pm \\
0.28 \\
\# \\
\end{array}$ \\
\hline Telophase, $\%$ & $1.69 \pm 0.28$ & $0.89 \pm 0.11$ & $1.01 \pm 0.08$ & $\begin{array}{c}1.35 \pm \\
0.14 \\
\# \\
\end{array}$ & $\begin{array}{c}0.89 \pm \\
0.08 \\
*\end{array}$ & $\begin{array}{c}1.3 \pm \\
0.08 \\
\#\end{array}$ & $\begin{array}{c}1.49 \pm \\
0.16 \\
\#\end{array}$ \\
\hline Interphase, $\%$ & $91.18 \pm 1.37$ & $95.77 \pm 0.27$ & $\begin{array}{c}94.48 \pm 0.27 \\
* / \# \#\end{array}$ & $\begin{array}{c}92.76 \pm \\
0.37 \\
\# \# \# \\
\end{array}$ & $\begin{array}{c}96.43 \pm \\
0.13 \\
* * / \# \\
\end{array}$ & $\begin{array}{c}92.23 \pm \\
0.31 \\
\# \# \# \\
\end{array}$ & $\begin{array}{c}92.0 \pm \\
1.22 \\
\# \# \\
\end{array}$ \\
\hline $\begin{array}{l}\text { Mitotic index, } \\
\text { c.u. }\end{array}$ & $8.82 \pm 1.37$ & $4.22+0.27$ & $5.52 \pm 0.27$ & $\begin{array}{c}7.24 \pm \\
0.37 \\
\# \# \# \\
\end{array}$ & $\begin{array}{c}3.57 \pm \\
0.13 \\
* * / \#\end{array}$ & $\begin{array}{c}7.76 \pm \\
0.31 \\
\# \# \#\end{array}$ & $\begin{array}{l}8.0 \pm \\
1.22 \\
\# \#\end{array}$ \\
\hline
\end{tabular}


NB: * - significance of difference with control $1(*-p<0.05 ; * *-p<0.01 ; * * *-p<$ $0.001)$, \# - significance of difference with control 2 (\# - p $<0.05$; \#\# - p $<0.01$; \#\#\# - $\mathrm{p}<$ 0.001 ).

The delayed development of the root system of onions was influenced by Bacillus strains 2-06-TS1, 875TS, 948P-1 TS $(1.66 \pm 0.09 ; 1.34 \pm 0.14$ and $0.35 \pm 0.03 \mathrm{~cm}$, respectively). Table 1 also shows that under the influence of the Bacillus 948P-1 TS strain, the number of roots was 2 times less. Comparison with control 2 revealed significant (3.35 8.4 times) stimulation of onion root system growth under the influence of the microbiota of frozen rocks, except for the Bacillus 948P-1 TS strain (Fig. 1).

It is known that the ratio of the average length of the aerial part to the average length of the root system is the coefficient of seedling symmetry [10]. The optimal number is $0.8-1.1$. Values above or below this limit indicate significant domination of one vegetative organ of the seedling over another. As a result, the conditions in which the plant develops are not comfortable for it. In the variant with the 2-06-TC1 strain, the symmetry coefficient is at the border of the optimum.
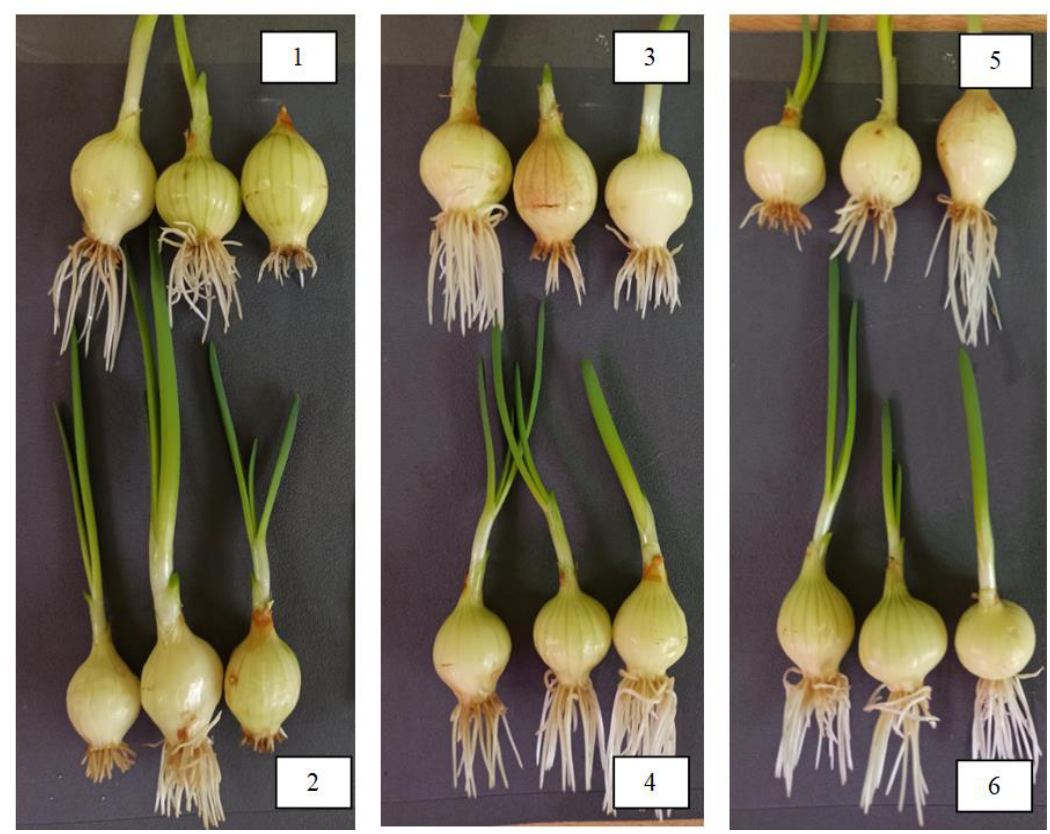

Fig. 1. Root and feather length of Allium cepa (1 - 312 TS; 2 - 948P-1 TS; 3 - 1257 TS; 4 - 2-06TS1; 5 - 875 TS; 6 - Control 1).

While analyzing leaf parameters, it's possible to judge the vegetative activity of onion seedlings (table 2). It was found that the studied strains had a negative effect on onion sprouts in comparison with control 1. This is especially noticeable in relation to Bacillus strains 312TS, 2-06-TS1 and 948P-1TS $(0.83 \pm 0.22 ; 2.52 \pm 0.71$ and $1.57 \pm 0.62$, respectively). When compared with control 2 , a significant (2 - 2.8 times) stimulation of the growth of the leaf part (feathers) of onions was established under the influence of the microbiota of frozen rocks, except for Bacillus strains 948P-1 TS and 312TS (Fig. 1). As shown earlier, the ratio of the average length of the ground part to the average length of the root system of onions (the coefficient of symmetry of seedlings) under the influence of the Bacillus 948P-1 TS strain was 2 times less than that of the standard indicators $(0.4 \pm 0.21)$. 
Table 2. The influence of microorganisms on vegetative parameters of Allium cepa.

\begin{tabular}{|c|c|c|c|c|c|c|c|}
\hline & Control 1 & Control 2 & $875 \mathrm{TS}$ & $\begin{array}{c}2-06- \\
\text { TS1 }\end{array}$ & $\begin{array}{c}\text { 948P-1 } \\
\text { TS }\end{array}$ & $312 \mathrm{TS}$ & $\begin{array}{c}1257 \\
\text { TS }\end{array}$ \\
\hline $\begin{array}{c}\text { Number of roots, } \\
\%\end{array}$ & 100 & $\begin{array}{c}63.44 \pm 6.27 \\
* *\end{array}$ & $\begin{array}{c}79.57 \pm \\
4.69 \\
* * / \#\end{array}$ & $\begin{array}{c}87.1 \pm \\
3.72 \\
* / \# \# \\
\end{array}$ & $\begin{array}{c}48.39 \pm \\
7.45 \\
* * / \#\end{array}$ & $\begin{array}{c}80.64 \pm \\
4.56 \\
* * / \#\end{array}$ & $\begin{array}{c}67.74 \pm \\
5.89 \\
* * / \#\end{array}$ \\
\hline $\begin{array}{l}\text { The ratio of roots } \\
\text { to feathers, c.u. }\end{array}$ & $0.59 \pm 0.2$ & $2.01 \pm 1.25$ & $\begin{array}{c}0.32 \pm \\
0.08 \\
* / \#\end{array}$ & $\begin{array}{c}1.33 \pm \\
0.73 \\
* / \#\end{array}$ & $\begin{array}{c}0.4 \pm \\
0.21 \\
* / \#\end{array}$ & $\begin{array}{c}4.09 \pm \\
0.62 \\
* * / \#\end{array}$ & $\begin{array}{c}4.06 \pm \\
3.37 \\
* / \#\end{array}$ \\
\hline
\end{tabular}

NB: * - significance of difference with control $1(*-p<0.01 ; * *-p<0.001)$, \# significance of difference with control 2 (\# - p < 0.01; \#\# - p < 0.001).

The significance of differences in mean values was research to study the effect of the microbiota of frozen soils on the morphophysiological parameters of onions by the method of analysis of variance (Table 3). When analyzing the data obtained, we proceeded from the fact: if the actual Fisher coefficient (F) was more than the critical one, then the mean gradations differ from each other, and the investigated independent factor (factors) significantly affects the change in the dependent data with a significance level $\alpha<0.05$, if less than the critical one, then the mean gradations do not differ from each other, and the factor(s) does not have a significant effect.

Table 3.The results of dispersion and correlation analyzes of the influence of microbiota on the morphophysiological parameters of Allium cepa, c.u.

\begin{tabular}{|c|c|c|c|c|c|c|c|c|c|c|}
\hline \multirow{2}{*}{$\begin{array}{l}\text { Dependentependent } \\
\text { factors }\end{array}$} & \multicolumn{2}{|c|}{$875 \mathrm{TS}$} & \multicolumn{2}{|c|}{ 2-06-TS1 } & \multicolumn{2}{|c|}{ 948P-1 TS } & \multicolumn{2}{|c|}{$312 \mathrm{TS}$} & \multicolumn{2}{|c|}{$1257 \mathrm{TS}$} \\
\hline & $\mathrm{F} / \alpha$ & $\mathrm{r} / \mathrm{p}$ & $\mathrm{F} / \alpha$ & $\mathrm{r} / \mathrm{p}$ & $\mathrm{F} / \alpha$ & $\mathrm{r} / \mathrm{p}$ & $\mathrm{F} / \alpha$ & $\mathrm{r} / \mathrm{p}$ & $\mathrm{F} / \alpha$ & $\mathrm{r} / \mathrm{p}$ \\
\hline \multirow{2}{*}{ Root length } & 11.39 & -0.65 & 2.73 & -0.38 & 31.59 & -0.82 & 0.89 & -0.23 & 4.19 & -0.46 \\
\hline & $\overline{0.004}$ & $\overline{0.004}$ & $\overline{0.118}$ & $\overline{0.118}$ & $\overline{<0.001}$ & $\overline{<0.001}$ & 0.359 & $\overline{0.359}$ & $\overline{0.057}$ & $\overline{0.057}$ \\
\hline \multirow{2}{*}{ Number of roots } & $\underline{1.45}$ & $\underline{-0.29}$ & $\underline{0.35}$ & $\underline{-0.15}$ & $\underline{10.65}$ & $\underline{-0.63}$ & 1.27 & -0.27 & $\underline{3.39}$ & -0.42 \\
\hline & $\overline{0.246}$ & $\overline{0.246}$ & $\overline{0.562}$ & $\overline{0.562}$ & $\overline{0.005}$ & $\overline{0.005}$ & $\overline{0.277}$ & $\overline{0.277}$ & $\overline{0.084}$ & $\overline{0.084}$ \\
\hline \multirow{2}{*}{ Feather length } & $\underline{6.01}$ & $\underline{-0.52}$ & 13.82 & -0.68 & 17.49 & -0.72 & 28.33 & -0.80 & 10.74 & -0.63 \\
\hline & $\overline{0.026}$ & $\overline{0.026}$ & $\overline{0.002}$ & $\overline{0.002}$ & $\overline{0.001}$ & $\overline{0.001}$ & $\overline{<0.001}$ & $\overline{<0.001}$ & $\overline{0.005}$ & $\overline{0.005}$ \\
\hline \multirow{2}{*}{$\begin{array}{l}\text { Number of } \\
\text { feathers }\end{array}$} & $\underline{0.00}$ & $\underline{0.00}$ & 0.271 & -0.13 & $\underline{3.57}$ & -0.43 & 3.57 & -0.43 & 2.75 & -0.38 \\
\hline & 1.0 & 1.0 & 0.61 & 0.61 & 0.077 & $\overline{0.077}$ & 0.077 & $\overline{0.077}$ & 0.117 & 0.117 \\
\hline
\end{tabular}

NB: F - Fisher's correlation coefficient; $\alpha$ is the significance level of the Fisher coefficient; $r$ is the correlation coefficient; $p$ - level of significance of the correlation coefficient.

According to the obtained results, among the analyzed microorganisms from permafrost rocks, all bacteria, to one degree or another, have a significant negative effect on the morphophysiological parameters of Allium cepa. Thus, the Bacillus 875TS strain with a significance level of $\alpha=0.004$ causes a delay in root growth $(\mathrm{F}=11.39)$ and, to a lesser extent, shoots of Allium cepa $(\mathrm{F}=6.01$ at $\alpha=0.026)$. The Bacillus 2-06-TS1 strain also significantly retards the growth of shoots of Allium cepa $(\mathrm{F}=13.82$ at $\alpha=0.002)$. The Bacillus 948P-1 TS strain exerts the most pronounced negative effect on the analyzed morphophysiological parameters. Under its influence, the length $(F=31.59$ at $\alpha<0.001)$ and the number of roots $(\mathrm{F}=10.65$ at $\alpha=0.005)$ decrease, as well as the length of the shoots $(\mathrm{F}$ $=17.49$ at $\alpha=0.001$ ). It was also established that at a significance level of $\alpha<0.001$ and a significance level of $\alpha<0.005$, there is a significant delay in the development of shoots in length when exposed to Bacillus strains 312 TS and $1257 \mathrm{TS}(\mathrm{F}=28.33$ and $\mathrm{F}=10.74$, respectively). 
The next stage of the research was the study of the phases of cell division in Allium cepa. It was registered that, in addition to changes in morphological parameters, Bacillus strains 875TS $(\mathrm{p}<0.05)$ and 948P-1TS $(\mathrm{p}<0.001)$ increase the interphase - the period of cell preparation for division (Table 1). During this period, the activity of enzymes involved in energy metabolism increases. Moreover, replication of DNA molecules and the synthesis of proteins - histones occurs, with which each DNA strand connects. In this case, RNA synthesis increases depending on the amount of DNA.

It is known that mitosis consists of four phases: prophase, metaphase, anaphase, telophase (Fig. 2). In prophase, the volume of the nucleus increases. Chromosomes spiral, become visible, shorten, thicken. It can be seen that they consist of two chromatids connected by a centromere. The centrioles diverge to the poles of the cell. And a spindle apparatus forms. The nucleoli and nuclear envelope dissolve by the end of the prophase, and the chromosomes enter the cytoplasm. Prophase is the lasting phase of mitosis. When exposed to Bacillus strains 875TS, 2-06-TS1 and 948P-1 TS, this phase is shortened, especially in the latter variant (3 times).

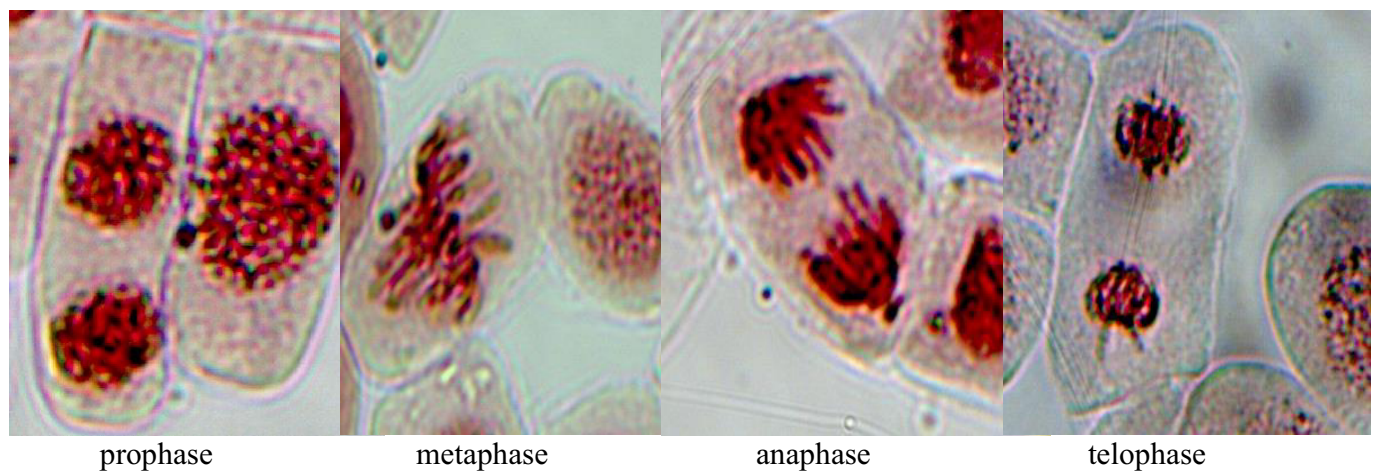

Fig. 2. Mitotic phases of Allium cepa.

At the same time, in controls 1 and 2, the number of cells in the metaphase was $2.28 \pm$ 0.47 and $1.03 \pm 0.09 \%$ of cases. Under the influence of Bacillus strains $875 \mathrm{TS}$ and $948 \mathrm{P}-\overline{1}$ $\mathrm{TS}$, the metaphase shortened, and in the latter variant, it was very short. At the same time, Bacillus strains do not affect the anaphase of cell division when the centromeres of the cell are divided, except for the 948P-1 TS strain, which shortens it by 2.2 times. Mitosis ends in telophase. It was found that Bacillus strains 875TS and 948P-1 TS shorten it by 1.7 and 1.9 times, respectively.

The mitotic index is one of the indicators of the intensity of cell division. It was marked that the proliferative capacity of cells is reduced by 2.5 times when exposed to only one Bacillus 948P-1 TS strain. Based on it, we can conclude that there is no mitotic or mitosisstimulating effect of the studied microorganisms from permafrost rocks.

The results of dispersion and correlation analyzes indicate that almost all studied bacteria of the genus Bacillus with a significance level of $\alpha<0.03$ cause a temporary delay in cell division (Table 4). The most pronounced such effectwas found for Bacillus strains 875TS and 948P-1 TS ( $\mathrm{F}=10.85$ at $\alpha=0.005$ and $\mathrm{F}=60.55$ at $\alpha<0.001$, respectively).At the same time, a mitotic or mitosis-stimulating effect was revealed in the Bacillus 312 TS strain $(\mathrm{F}=5.42$ at $\alpha=0.033)$. 
Table 4. The results of dispersion and correlation analyses of the influence of the microbiota of frozen soils at the stage of the cell cycle of development of Allium cepa, c.u.

\begin{tabular}{|c|c|c|c|c|c|c|c|c|c|c|}
\hline \multirow{2}{*}{$\begin{array}{l}\text { Independent } \\
\text { fependentors } \\
\text { factors }\end{array}$} & \multicolumn{2}{|c|}{$875 \mathrm{TS}$} & \multicolumn{2}{|c|}{ 2-06-TS1 } & \multicolumn{2}{|c|}{ 948P-1 TS } & \multicolumn{2}{|c|}{$312 \mathrm{TS}$} & \multicolumn{2}{|c|}{$1257 \mathrm{TS}$} \\
\hline & $\mathrm{F} / \alpha$ & $\mathrm{r} / \mathrm{p}$ & $F / \alpha$ & $\mathrm{r} / \mathrm{p}$ & $\mathrm{F} / \alpha$ & $\mathrm{r} / \mathrm{p}$ & $\mathrm{F} / \alpha$ & $\mathrm{r} / \mathrm{p}$ & $\mathrm{F} / \alpha$ & $\mathrm{r} / \mathrm{p}$ \\
\hline \multirow{2}{*}{ Prophase } & 3.93 & -0.44 & 5.1 & -0.49 & 14.92 & -0.69 & $\underline{0.81}$ & -0.22 & 4.95 & -0.5 \\
\hline & $\overline{0.065}$ & $\overline{0.065}$ & $\overline{0.04}$ & $\overline{0.04}$ & $\overline{0.001}$ & $\overline{0.001}$ & $\overline{0.383}$ & $\overline{0.383}$ & $\overline{0.04}$ & $\overline{0.04}$ \\
\hline \multirow{2}{*}{ Metaphase } & 14.64 & -0.69 & $\underline{5.47}$ & -0.51 & 40.07 & -0.85 & 2.80 & -0.39 & 7.14 & -0.5 \\
\hline & $\overline{0.001}$ & $\overline{0.001}$ & $\overline{0.03}$ & $\overline{0.03}$ & $\overline{<0.001}$ & $\overline{<0.001}$ & $\overline{0.113}$ & $\overline{0.113}$ & 0.02 & 0.02 \\
\hline \multirow{2}{*}{ Anaphase } & $\underline{8.07}$ & -0.58 & $\underline{0.58}$ & -0.19 & 25.75 & -0.79 & $\underline{0.41}$ & -0.16 & $\underline{3.0}$ & -0.4 \\
\hline & $\overline{0.012}$ & $\overline{0.012}$ & $\overline{0.46}$ & $\overline{0.456}$ & $\overline{<0.001}$ & $\overline{<0.001}$ & $\overline{0.53}$ & $\overline{0.53}$ & $\overline{0.1}$ & $\overline{0.1}$ \\
\hline \multirow{2}{*}{ Telophase } & 20.59 & -0.75 & 8.64 & -0.59 & 28.77 & -0.80 & 6.47 & -0.54 & 6.89 & -0.5 \\
\hline & $\overline{<0.001}$ & $<\overline{0.001}$ & $\overline{0.01}$ & $\overline{0.01}$ & $\overline{<0.001}$ & $<\overline{0.001}$ & $\overline{0.022}$ & $\overline{0.022}$ & $\overline{0.02}$ & $0 . \overline{02}$ \\
\hline \multirow{2}{*}{ Interphase } & 37.18 & $\underline{0.84}$ & 10.58 & $\underline{0.63}$ & $\underline{51.72}$ & $\underline{0.87}$ & $\underline{33.11}$ & $\underline{0.82}$ & $\underline{5.65}$ & $\underline{0.51}$ \\
\hline & $\overline{<0.001}$ & $<\overline{0.001}$ & 0.01 & $\overline{0.01}$ & $\overline{<0.001}$ & $<\overline{0.001}$ & $\overline{<0.001}$ & $<\overline{0.001}$ & $\overline{0.03}$ & $\overline{0.03}$ \\
\hline \multirow{2}{*}{ Mitosis } & $\underline{0.01}$ & $\underline{0.25}$ & 1.14 & $\underline{0.26}$ & 11.64 & -0.65 & 5.42 & $\underline{0.50}$ & 0.42 & $\underline{0.16}$ \\
\hline & 0.921 & 0.921 & 0.3 & 0.3 & $\overline{0.004}$ & $\overline{0.004}$ & 0.033 & $\overline{0.033}$ & $\overline{0.53}$ & 0.53 \\
\hline \multirow{2}{*}{ Mitotic index, c.u. } & 10.85 & -0.64 & 2.13 & -0.34 & 60.55 & -0.89 & $\underline{0.71}$ & $\underline{-0.21}$ & $\underline{0.39}$ & -0.2 \\
\hline & 0.005 & 0.005 & 0.16 & 0.16 & $<0.001$ & $<0.001$ & $\overline{0.411}$ & 0.411 & 0.54 & 0.54 \\
\hline
\end{tabular}

NB: F - Fisher's correlation coefficient; $\alpha$ is the significance level of the Fisher coefficient; $r$ is the correlation coefficient; $p$ - level of significance of the correlation coefficient.

Thus, among the analyzed microorganisms of dispersed soils that passed into a frozen state, it was established that only Bacillus 948P-1 TS and 312 TS strains have a significant effect on mitosis. Moreover, their influence is multidirectional. So, if the Bacillus 948P-1 TS strain inhibits cell division ( $\mathrm{F}=11.64$ at $\alpha=0.004$ ), then the Bacillus 312 TS strain, on the contrary, stimulates mitosis $(\mathrm{F}=5.42$ at $\alpha=0.033)$.

Noteworthy is the fact that all studied bacteria of the genus Bacillus with a significance level of $\alpha<0.03$ cause a temporary delay in cell division. It allows the cell to grow and makes it possible to assess the suitability of external and internal conditions for DNA duplication and subsequent division. In addition, Bacillus strains 875TS and 948P-1 TS inhibit the proliferative capacity of Allium cepa cells $(\mathrm{F}=10.85$ at $\alpha=0.005$ and $\mathrm{F}=$ 60.55 at $\alpha<0.001$, respectively), indicating the absence of mitotic or mitosis-stimulating action.

\section{Discussion}

Our research has shown that microorganisms from dispersed flooded rocks that have passed into a frozen state have a toxic effect. It manifests in the growth retardation of roots (strain Bacillus 875TS) and shoots of Allium cepa (strains Bacillus 875TS and Bacillus 2-06-TS1). Bacillus 948P-1 TS strain has the most pronounced toxic effect on Allium cepa. Under its influence, it is recorded a decrease in the length and number of roots. There is also a decrease in the shoot length. At the same time, a significant delay in the development of shoots in length occurs under the influence of Bacillus strains 312 TS and 1257 TS.

Apparently, the revealed toxic effect is due to the negative influence of Bacillus strains on the phases of cell division, in particular, on mitosis. At the same time, strains Bacillus 875TS and 948P-1 TS have a significant effect on the stage of the cell cycle of onion development, suppressing the mitotic activity of cells. The Bacillus 312 TS strain, on the contrary, stimulates a mitotic (mitosis-stimulating) effect. It is possible that bacteria of the genus Bacillus, causing a temporary delay in cell division, allow the cell to grow and make 
it possible to assess the suitability of external and internal conditions for DNA duplication and subsequent division. At the same time, in the interphase, the activity of enzymes participating in energy metabolism increases, replication of DNA molecules occurs, synthesis of proteins - histones, with which each DNA strand connect. RNA synthesis increases according to the amount of DNA.

\section{Conclusions}

All investigated microorganisms of the genus Bacillus cause a negative effect on the morphometric parameters of Allium cepa. According to the degree of manifestation of the negative influence, the bacteria arrange in the following order:

- strain 2-06-TS1;

- strains 875TS, 312 TS and 1257 TS;

- strain 948P-1 TS.

Bacillus strains $875 \mathrm{TS}$ and 948P-1 TS inhibit the proliferative ability of Allium cepa cells, which indicates that they have no mitotic or mitosis-stimulating effect. Bacillus strain $312 \mathrm{TS}$, on the contrary, stimulates mitosis.

The research work was carried out according to the state assignment for 2021-2030 Spatio-temporal phenomena and processes occurring in the waters of the land of Siberia in the modern technogenesis and climate change (Priority direction 1.5.11. Program 1.5.11.1).

\section{References}

1. T. Collins, R. Margesin, Appl. Microbiol. Biotechnol., 103 (2019)

2. N.S. Panikov, Soil Biology, 16, 9 (2009)

3. L.R. Renxing, Z. Li, M. Vetter, T. Vishnivetskaya, O. Zanina, K. Lloyd, S. Pfiffner, E. Rivkina, W. Wang, J. Wiggins, J. Miller, R. Hettich, T. Onstott, Microbiome, 9 (2021)

4. J.K. Jansson, N. Tas, Nat Rev Microbiol., 12 (2014)

5. A.V. Brouchkov, V.P. Melnikov, Yu.G. Sukhovei, G.I. Griva, V.E. Repin, L.F. Kalenova, E.V. Brenner, A.M. Subbotin, Y.B. Trofimova, M. Tanaka, T. Katayama, M. Utsumi, Adv. Gerontol., 1 (2011)

6. A.M. Subbotin, S.A. Petrov, V.A. Malchevskiy, D.A. Hrupa, XI International Conference «Plant Cell Biology in Vitro and Biotechnology» (Minsk, 2018)

7. A.S. Labinskaya, E.G. Volina, Manual of Medical Microbiology. General and sanitary microbiology (BINOM, Moscow, 2008)

8. G. Fiskesjö, Hereditas, 102 (1985)

9. I.M. Prohorova, M.I. Kovaleva, A.N. Fomicheva, Methodical instructions, 32 (JarGU, Jaroslavl, 2003)

10. D.F. Zhirnova, I.V. Pantyukhov, I.V. Goldman, Bulletin of the Krasnoyarsk State Agrarian University, 1 (2008) 